\title{
Adverse Effects of Nitroxynil and Albendazole on rabbits
}

\author{
Eman A. Elalfy ${ }^{1}$, Azza Hassan ${ }^{1}$, Magdy Amer ${ }^{2}$ \\ ${ }^{1}$ Animal Health Research Institute, Mansoura \\ ${ }^{2}$ Pharmacologydepartment, Faculty of Veterinary Medicine, Mansoura University, 35516, Egypt
}

\section{ARTICLE HISTORY}

Received: 05.07.2020

Revised: 12.1 .2022

Accepted: 12.10 .2022

Correspondence to: Eman Mohammed;

Tel: +201099443698; Email:

emanelalfy79@gmail.com

\begin{abstract}
Objective: The present study aims to investigate the possible adverse effects of the subcutaneous injection of nitroxynil and oral administration of albendazole in rabbits.

Design: Randomized controlled experimental study.

Animals: 18 New Zealand rabbits of $1.50 \pm 0.5 \mathrm{~kg}$ body weight, were allocated randomly into three groups $(\mathrm{n}=6)$.

Procedures: Group A served as control, the group B was treated with albendazole ( $20 \mathrm{mg} / \mathrm{kg} \mathrm{B}$. wt.) orally and the group $\mathrm{C}$ was treated with nitroxynil $(10 \mathrm{mg} / \mathrm{kg} \mathrm{B}$. wt.) subcutaneously. Blood samples were collected at $1^{\text {st }}, 7^{\text {th }}$ and $14^{\text {th }}$ days post drugs administration for hematological and biochemical determination. In addition, histopathological examination of liver, kidney and intestine specimens were performed.

Results: The obtained results evoked a significant decrease in RBCs, PCV, Hb, WBCs, lymphocytes, neutrophils, GSH and catalase values in group B and C compared with that group A. On the other hand, group B and C elevated serum ALT, AST, urea, creatinine, and MDA significantly $(P \leq 0.05)$ compared with group $A$.

Key words: Nitroxynil, albendazole, GSH, MDA, CAT, rabbit
\end{abstract}

\section{MATERIALS AND METHODS}

\section{INTRODUCTION}

Rabbits play an important role in economy development as their production is still a new enterprise and is mainly a small-holder system that has advantages over the other livestock system because of the small rabbit's body size, high rate of reproduction, adaptability to inexpensive housing and useful by-products [1]

Infection of livestock with parasites has a great burden on animal's health that leads to great losses in the productivity of these animals and economic losses to the farmers [2]. Helminth infections have the impact of decreased productivity in livestock animals [3].

The control of helminthiasis depends almost on the use of anthelmintic drug due to the ease of administration and low cost of therapy compared to other methods of control for improving livestock productivity [2].

Nitroxynil is a nitrate derivative compound that has a flukicide effect of a low spectrum activity against fascioliasis and roundworms[4]. Nitroxyinil has a great efficacy against adult liver flukes (Fasciola hepatica), a few gastrointestinal roundworms as Bunostomum, Haemonchus, Oesophagostomum, and Parafilaria bovicola and against myiases [5].

Albendazole is an anthelmintic drug used for the treatment of many parasitic worms in human and animals of a broad-spectrum activity against adult stages, eggs and larvae. It is effective against gastrointestinal nematodes [6]. This study evaluated the oxidative stress effects, some hematological and biochemical alterations accompanied the therapeutic doses of nitroxynil and albendazole in rabbits.

\subsection{Drugs}

Albendazole :( Albendazole 2.5\%) ${ }^{\circ}$ suspended solution was supplied by ArabcoMedCo., Egypt. at dose of $20 \mathrm{mg} / \mathrm{kg}$ orally[7]. Nitroxynil (Fasciolid 25\%) ${ }^{\circ}$ injectable and sterile solution was supplied by CIDCo., Egypt. at dose of $10 \mathrm{mg} / \mathrm{kg}$ subcutaneously [8].

\subsection{Experimental design}

This study was performed on 18 New Zealand rabbits of $1.5 \pm 0.5 \mathrm{~kg} \mathrm{~B}$. wt. The animals were housed under standard laboratory conditions in polypropylene cages, provided with food and water ad libitum. This investigation was performed at Mansoura Experimental Research Center (MERC), Mansoura University and approved by scientific research Ethical Committee, Faculty of Veterinary Medicine, Mansoura University Rabbits were Group A: (control) was treated with saline $(1 \mathrm{ml} /$ rabbit) intraperitoneally. Group B: was treated with albendazole at dose of $20 \mathrm{mg} / \mathrm{kg} \mathrm{B}$. wt. orally once daily for 10 days. Group C: was treated with nitroxynil as a single subcutaneous dose of $10 \mathrm{mg} / \mathrm{kg} \mathrm{B}$. wt.

\subsection{Collection of samples}

Blood samples were collected at $1^{\text {st }}, 7^{\text {th }}$ and $14^{\text {th }}$ days after drug administration. The blood was collected from ear vein on EDTA for hematological studies. Another sample of blood were collected and allowed to clot for serum separation for biochemical studies. 


\subsection{Methods}

Red blood cell counts (RBCs), white blood cells count (WBCs), differential leukocytic count, $\mathrm{Hb}$ concentration and PCV\% were determined [9].

Liver function test as ALT and AST[10], kidney function test as serum urea [11]and creatinine [12].

Serum oxidative stress and antioxidant enzymes as reduced glutathione[13], malondialdehyde [14]and catalase[15]

Liver, kidney and intestinal tissues were collected after rabbits slaughtering and were fixed in $10 \%$ neutral buffered formalin for histopathological examination[16].

Data were analyzed using the statistical package for social science (SPSS), 15.0 software, 2008)[17].

\section{RESULTS}

\subsection{Effects on blood picture}

The current study indicated that there was a significant decrease in RBCs values in the the group treated with albendazole in compareson with that of the control one. On the other hand, the group treated with nitroxynil showed a significant decrease in RBCs counts after one day and one week of treatment compared to that of the control group. Albendazole decreased RBCs significantly compared to nitroxynil treated one.

PCV\% showed a significant decrease in the groups treated with albendazole and nitroxynil in comparison to that of control group after one day and one week of treatment.

Table 1. Effects of nitroxynil (10 mg/kg,s.c) and albendazole $\left(20 \mathrm{mg} / \mathrm{kg}\right.$, po) on the $\mathrm{RBC}_{\mathrm{s}}, \mathrm{PCV} \%$ and $\mathrm{Hb}$ of rabbits. (Mean $\left.\pm \mathrm{SE}\right) \mathrm{N}=5$

\begin{tabular}{|c|c|c|c|c|c|c|c|c|c|c|}
\hline & \multirow[b]{2}{*}{ Group } & \multicolumn{3}{|c|}{$\begin{array}{c}\mathrm{RBC}_{\mathrm{s}} \\
\left(10^{12} / \mathrm{L}\right)\end{array}$} & \multicolumn{3}{|c|}{$\begin{array}{l}\text { PCV } \\
(\%)\end{array}$} & \multicolumn{3}{|c|}{$\begin{array}{c}\mathrm{Hb} \\
(\mathrm{g} / \mathrm{L})\end{array}$} \\
\hline & & $1^{\text {st }}$ day & $7^{\text {th }}$ day & $14^{\text {th }}$ day & $1^{\text {st }}$ day & $7^{\text {th }}$ day & $14^{\text {th }}$ day & $1^{\text {st }}$ day & $7^{\text {th }}$ day & $14^{\text {th }}$ day \\
\hline G1 (A) & & $5.84 \pm .02^{a}$ & $5.8 \pm .40^{a}$ & $5.79 \pm .03^{a}$ & $35.30 \pm .03^{a}$ & $35.34 \pm .03^{a}$ & $34.7 \pm .40^{a}$ & $12.1 \pm .19^{a}$ & $11.57 \pm .3^{a}$ & $11.87 \pm .13^{a}$ \\
\hline G2 (B) & & $5.16 \pm .06^{c}$ & $4.12 \pm .02^{c}$ & $5.44 \pm .03^{b}$ & $32.72 \pm .02^{b}$ & $28.1 \pm 0.59^{c}$ & $33.99 \pm .76^{a}$ & $\pm .44^{b} 10.68$ & $\pm .22^{b} 9.42$ & $\pm .27^{\text {a }} 10.53$ \\
\hline G3 (C) & & $5.68 \pm .15^{b}$ & $4.95 \pm .03^{b}$ & $5.83 \pm .04^{a}$ & $36.22 \pm .02^{c}$ & $30.1 \pm .61^{b}$ & $30.18 \pm .29^{b}$ & $\pm .04^{\text {a }} 12.06$ & \pm .25 a 11.05 & $10.59 \pm .15^{b}$ \\
\hline
\end{tabular}

Means within the same raw carrying different superscripts are significant at $(p<0.05)$.

There was a significant decrease in $\mathrm{Hb}$ values in albendazole treated group after one day and one week of therapy compared to the control one. Also, group treated with nitroxynil decreased $\mathrm{Hb}$ after two weeks of dosing when compared to control group.

The findings represented the effects of albendazole and nitroxynil on total leucocytic count in rabbits showed that both group treated with albendazole and nitroxynil showed a significant decrease in the total erythrocytic count, lymphocytes and neurophils in comparison with that of the control group. Also, the group treated with nitroxynil revealed a significant decrease in WBCs counts after two weeks of treatment in comparison with that of albendazole treated one.

The results showed a significant decrease in lymphocytes after one week of albendazole adminstration compared to nitroxynil treated group. In the same manner, nitroxynil and albendazole evoked a sgnificant decrease in neutrophils after one and two weeks of treatment. On the other hand, there werenot any significant diffrences between groups in esinophilic, monocytic and basophilic counts.

\subsection{Biochemical determinations}

ALT results revealed a significant increase in the groups treated with albendazole and nitroxynil compared with control group. Also, ALT values were increased significantly in nitroxynil treated group after one day and one week of dosing comparasion to albendazole treated one.

Additionally, AST results showed a significant increase after nitroxynil and albendazole treatment comparing to the control group, However, albendazole treated group indicated a significant increase in AST values after one day of therapy compared to that of nitroxynil treated group, while nitroxynil evoked a significant decrease after one week and two weeks of dosing compared to albendazole treated group.

In the existing study Serum creatinine recorded a significant increase after one week and two weeks of albendazole treatment. While nitroxynil elevated serum creatinine after two weeks of dosing compared to control group. Similarly, albendazole treated group represented a significant increase in serum creatinine compared to that was treated with nitroxynil.

Additionally, serum urea was increased significantly in the two treated groups with the therapeutic doses of nitroxynil and albendazole after one day, one week and two weeks of dosing. In the same manner, albendazole treated group represented a significant increase in serum urea compared to that was treated with nitroxynil.

Albendazole and nitroxynil treated groups evoked a significant decrease in GSH after one day, one week and two weeks of treatment compared to control group. While the 
nitroxynil treated group elicited a significant decrease after one week of therapy compared to albendazole treated group.

Table 2. Effects of nitroxynil (10 mg/kg, S.C), and albendazole (20 mg/kg, PO) on the total and the differential leucocytic count of rabbits. (Mean $\pm 32 \mathrm{SE}$ ) $\mathrm{N}=5$

\begin{tabular}{|c|c|c|c|c|}
\hline \multicolumn{2}{|c|}{ Group } & $\begin{array}{c}\text { G } 1 \\
\text { Control }\end{array}$ & $\begin{array}{c}\text { G } 2 \\
\text { Albendazole }\end{array}$ & $\begin{array}{c}\text { G 3 } \\
\text { Nitroxynil }\end{array}$ \\
\hline \multirow{3}{*}{$\begin{array}{l}\text { Total leukocytic count } \\
\left(10^{3 / \mu l}\right)\end{array}$} & $1^{\text {st }}$ day & $12.27 \pm .15^{a}$ & $9.66 \pm .21^{b}$ & $11.26 \pm .23^{b}$ \\
\hline & $7^{\text {th }}$ day & $12.13 \pm .19^{a}$ & $8.61 \pm .72^{b}$ & $8.57 \pm .22^{b}$ \\
\hline & $14^{\text {th }}$ day & $12.33 \pm .18^{a}$ & $11.47 \pm .28^{b}$ & $6.99 \pm .27^{c}$ \\
\hline \multirow{3}{*}{$\begin{array}{l}\text { Lymphocytes } \\
\left(10^{3 / \mu l)}\right.\end{array}$} & $1^{\text {st }}$ day & $4.44 \pm .22^{a}$ & $3.71 \pm .21^{b}$ & $4.20 \pm 0.15^{\mathrm{a} b}$ \\
\hline & $7^{\text {th }}$ day & $4.38 \pm .2^{\mathrm{a}}$ & $2.57 \pm .12^{c}$ & $3.47 \pm .08^{b}$ \\
\hline & $14^{\text {th }}$ day & $4.3 \pm .24^{a}$ & $1.81 \pm .17^{b}$ & $2.19 \pm .0^{b}$ \\
\hline \multirow{3}{*}{$\begin{array}{l}\text { Neutrophils } \\
\left(10^{3 / \mu l}\right)\end{array}$} & $1^{\text {st }}$ day & $4.43 \pm 0.22^{a}$ & $4.50 \pm .06^{a}$ & $4.59 \pm .05^{a}$ \\
\hline & $7^{\text {th }}$ day & $4.14 \pm .18^{a}$ & $3.32 \pm .06^{b}$ & $3.97 \pm .03^{b}$ \\
\hline & $14^{\text {th }}$ day & $4.70 \pm .15^{a}$ & $3.67 \pm .04^{b}$ & $3.44 \pm .06^{b}$ \\
\hline \multirow{3}{*}{$\begin{array}{l}\text { Monocytes } \\
\left(10^{3 / \mu l)}\right.\end{array}$} & $1^{\text {st }}$ day & $.73 \pm .03^{a}$ & $.76 \pm .01^{\mathrm{a}}$ & $.74 \pm .01^{a}$ \\
\hline & $7^{\text {th }}$ day & $.72 \pm .02^{a}$ & $0.69 \pm .01^{a}$ & $.76 \pm .04^{a}$ \\
\hline & $14^{\text {th }}$ day & $.71 \pm .02^{\mathrm{a}}$ & $0.71 \pm .07^{a}$ & $0.69 \pm .0^{a}$ \\
\hline \multirow{3}{*}{$\begin{array}{l}\text { Eosinophils } \\
\left(10^{3 / \mu l)}\right.\end{array}$} & $1^{\text {st }}$ day & $.34 \pm .01^{a}$ & $.27 \pm .04^{a}$ & $.26 \pm .03^{a}$ \\
\hline & $7^{\text {th }}$ day & $.30 \pm .03^{a}$ & $.37 \pm .02^{a}$ & $.37 \pm .05^{a}$ \\
\hline & $14^{\text {th }}$ day & $.34 \pm .01^{a}$ & $.33 \pm .06^{a}$ & $.30 \pm .02^{a}$ \\
\hline \multirow{3}{*}{$\begin{array}{l}\text { Basophils } \\
\left(10^{3 / \mu l}\right)\end{array}$} & $1^{\text {st }}$ day & $.01 \pm .01^{\mathrm{a}}$ & $.0 \pm 0^{\mathrm{a}}$ & $0 \pm 0^{a}$ \\
\hline & $1^{\text {st }}$ week & $.02 \pm .01^{a}$ & $.02 \pm .01^{a}$ & $.04 \pm .02^{\mathrm{a}}$ \\
\hline & week $2^{\text {nd }}$ & $.03 \pm .01^{a}$ & $.04 \pm .02^{a}$ & $.05 \pm .02^{a}$ \\
\hline
\end{tabular}

Means within the same raw carrying different superscripts are significant at $(p<0.05)$.

Table 3. Table 3. Effects of nitroxynil ( $10 \mathrm{mg} / \mathrm{kg}, \mathrm{S} . \mathrm{C})$, and albendazole $(20 \mathrm{mg} / \mathrm{kg}$, PO) on the activity of liver enzymes (serum ALT and $\mathrm{AST}$ ) of rabbits. (Mean $\pm \mathrm{SE}) \mathrm{N}=5$

\begin{tabular}{|c|c|c|c|c|c|c|}
\hline \multirow[b]{2}{*}{ Group } & \multicolumn{3}{|c|}{ ALT (U/L) } & \multicolumn{3}{|c|}{ AST (U/L) } \\
\hline & $1^{\text {st }}$ day & $7^{\text {th }}$ day & $14^{\text {th }}$ day & $1^{\text {st }}$ day & $7^{\text {th }}$ day & $14^{\text {th }}$ day \\
\hline G1(A) & $22.56 \pm .62^{c}$ & $21.57 \pm .74^{c}$ & $22.68 \pm .46^{b}$ & $14.37 \pm .19^{b}$ & $13.87 \pm .32^{c}$ & $13.97 \pm .03^{c}$ \\
\hline G1(B) & $24 \pm .64^{b}$ & $26.37 \pm .55^{b}$ & $32.13 \pm .75^{a}$ & $14.29 \pm .19^{b}$ & $19.05 \pm .1^{\mathrm{a}}$ & $20.74 \pm .46^{a}$ \\
\hline G1(C) & $29.45 \pm .59^{a}$ & $30.54 \pm .64^{a}$ & $33.37 \pm .49^{a}$ & $16.07 \pm .41^{\mathrm{a}}$ & $15.65 \pm .14^{b}$ & $17 \pm .32^{b}$ \\
\hline
\end{tabular}

Means within the same raw carrying different superscripts are significant at $(p<0.05)$.

The present work mirrored a significant decrease in catalase after one day, one week and two weeks in the group was treated with albendazole and nitroxynil in comparison to the control group. Also, there was a significant decrease in catalase in the group treated with nitroxynil after one week and two weeks compared to albendazole treated group. 
Table 4. Effects of nitroxynil (10 mg/kg,S.C) and albendazole (20 mg/kg, PO) on the activity of serum creatinine and urea of rabbits. (Mean $\pm \mathrm{SE}) \mathrm{N}=5$

\begin{tabular}{lllllll} 
& \multicolumn{2}{l}{ Serum creatinine $(\mathrm{mg} / \mathrm{dl})$} & \multicolumn{2}{l}{ Serum urea $(\mathrm{mg} / \mathrm{dl})$} \\
Group & $1^{\text {st }}$ day & $7^{\text {th }}$ day & $1^{\text {th }}$ day & $1^{\text {st }}$ day & $7^{\text {th }}$ day & $14^{\text {th }}$ day \\
G1(A) & $.78 \pm .0^{\mathrm{a}}$ & $.77 \pm .01^{\mathrm{b}}$ & $.76 \pm .01^{\mathrm{c}}$ & $33.37 \pm .58^{\mathrm{c}}$ & $32.77 \pm .12^{\mathrm{c}}$ & $31.78 \pm .47^{\mathrm{c}}$ \\
G1(B) & $.77 \pm .02^{\mathrm{a}}$ & $.81 \pm .01^{\mathrm{a}}$ & $.81 \pm .01^{\mathrm{a}}$ & $40.46 \pm .55^{\mathrm{a}}$ & $47.55 \pm .59^{\mathrm{a}}$ & $41.89 \pm .89^{\mathrm{a}}$ \\
G1(C) & $.77 \pm .01^{\mathrm{a}}$ & $.78 \pm .01^{\mathrm{b}}$ & $.79 \pm .01^{\mathrm{b}}$ & $37.31 \pm .052^{\mathrm{b}}$ & $37.97 \pm .19^{\mathrm{b}}$ & $34.20 \pm .13^{\mathrm{b}}$
\end{tabular}

Means within the same raw carrying different superscripts are significant at $(p<0.05)$.

Table 5. Effects of of nitroxynil (10 mg/kg, S.C) and albendazole (20 mg/kg, PO) on catalase, reduced glutathione and malondialehyde of rabbits. (Mean $\pm \mathrm{SE}$ ) $\mathrm{N}=5$

\begin{tabular}{|c|c|c|c|c|c|c|c|c|c|}
\hline \multicolumn{3}{|c|}{ GSH (U/ml) } & \multicolumn{3}{|c|}{ CAT (mg/dl) } & & \multicolumn{3}{|c|}{ MDA (nmol/ ml) } \\
\hline Group & $1^{\text {st }}$ day & $7^{\text {th }}$ day & $14^{\text {th }}$ day & $1^{\text {st }}$ day & $7^{\text {th }}$ day & $14^{\text {th }}$ day & $1^{\text {st }}$ day & $7^{\text {th }}$ day & $14^{\text {th }} d a y$ \\
\hline G1 (A) & $.75 \pm .01^{\mathrm{a}}$ & $.75 \pm .03^{a}$ & $.81 \pm .08^{a}$ & $255.65 \pm 2.90^{a}$ & $255.66 \pm 2.85^{a}$ & $254.60 \pm 1.84^{a}$ & $1.34 \pm .02^{b}$ & $1.35 \pm .02^{c}$ & $1.36 \pm .01^{c}$ \\
\hline G2 (B) & $.45 \pm .01^{b}$ & $.40 \pm .03^{b}$ & $.15 \pm .02^{b}$ & $233.73 \pm 8.78^{b}$ & $195.49 \pm 2.84^{b}$ & $126.59 \pm 12.4^{b}$ & $4.43 \pm .53^{a}$ & $5.28 \pm .19^{a}$ & $2.75 \pm .13^{b}$ \\
\hline G3 (C) & $.52 \pm .04^{b}$ & $.22 \pm .01^{c}$ & $.22 \pm .01^{b}$ & $212.40 \pm 1.13^{c}$ & $181.03 \pm 2.37^{c}$ & $115.23 \pm 1.16^{c}$ & $1.48 \pm .02^{b}$ & $3.45 \pm .03^{b}$ & $6.36 \pm .25^{a}$ \\
\hline
\end{tabular}

Means within the same raw carrying different superscripts are significant at $(p<0.05)$.

MDA results revealed a significant increase in group treated with albendazole after one day, one week and two weeks of treatment compared to the control group. On the other hand, nitroxynil elevated the MDA after one week and two weeks of dosing compared to the control one. Nitroxynil caused a significant increase in serum MDA after two weeks of treatment compared to albendazole, while albendazole evoked a significant increase in MDA after one week of treatment compared to nitroxynil.

The liver of the group A showed normal histological picture. There was normal arrangement and normal structure of kidney glomeruli and tubules of control group. Duodenum showed normal arrangement and structure of intestinal villi and crypts, (Figure 1).

On the other hand, liver of the group B treated with albendazole (20 mg/kg, S.C), showed congested hepatic pelvis (arrows), with congested portal veins (thin arrows) with periductal mononuclear cells infiltration (thick arrows) and mild degenerated hepatocytes (arrows). The kidney of the group B treated with albendazole $(20 \mathrm{mg} / \mathrm{kg}, \mathrm{S} . \mathrm{C})$, showed congested glomerulus (thick arrows), tubular dilatation with hyaline casts (arrows) and duodenum of the group B treated with albendazole $(20 \mathrm{mg} / \mathrm{kg}, \mathrm{S} . \mathrm{C})$, showed congested belvis (arrows) in lamina propria with oedema (star), as showed in Fig (2).

Wherever, the liver of the group $C$ treated with nitroxynil showed severe periductal hemorrhage (arrows) with hydropic degeneration of hepatocytes (star). Kidney of the group $\mathrm{C}$ showed necrotic glomeruli signs of acute inflammation (thick arrows) with tubular dilatation and tubular cast (thin arrow) and duodenum of the group $C$ showed increased lymphocytic population in lamina propria villi (arrow) with edema in submucosa (star), as illustrated in Fig (3).

\section{DISCUSSION}

The decrease in total erythrocyte count, PCV, $\mathrm{Hb}$ and total leukocytic count in rabbits may be due to the increase of albendazole absorption because rabbits The recorded results agreed with that of Gray, Presson [19]who recorded a decrease in RBC, $\mathrm{Hb}$ and PCV values that could be due to oxidative stress arising from the metabolic interactions of albendazole. Also, Opatrny, Snell [20]who found that CBC results after albendazole therapy revealed anemia and leukopenia, and/or thrombocytopenia. In the same manner,Graham, Garner [21], recorded anemia, leukopenia and thrombocytopenia noted during albendazole therapy in a rabbit that caused immediate cessation of the drug. 

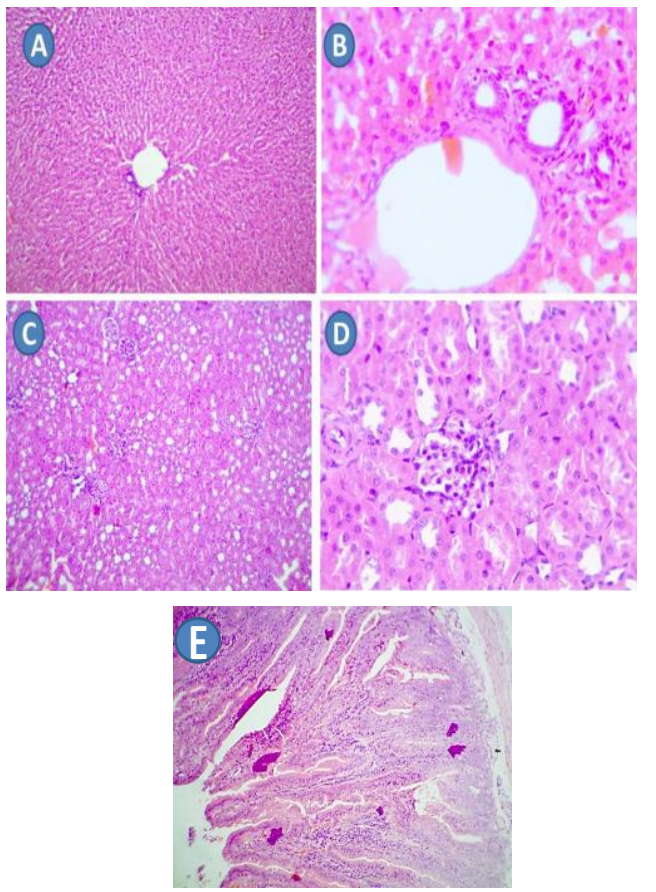

Figure 1: A\&B: Liver of control group showing normal histological picture. C\&D: Kidney of control group showing normal arrangement and structure of glomeruli and tubules. E: Duodenum showing normal arrangement and structure of intestinal villi and crypts. H\&E. A, C, E X100, B, D X200.

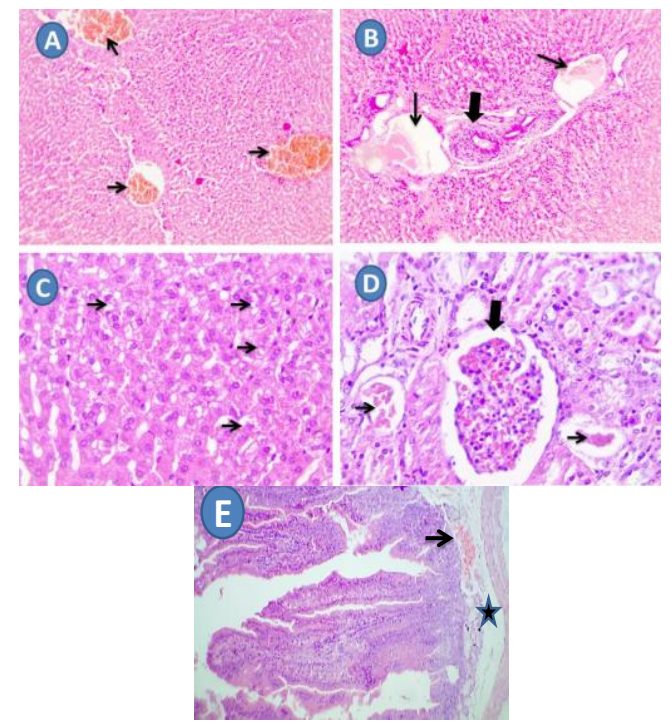

Figure 2: A\&C: Liver of the group treated with albendazole $(20 \mathrm{mg} / \mathrm{kg}, \mathrm{S} . \mathrm{C})$, showing congested hepatic pelvis (arrows), B: Showing congested portal veins (thin arrows) with periductal mononuclear cells infiltration (thick arrows).C: Mild degenerated hepatocytes (arrows). D: Kidney of the group treated with albendazole $(20 \mathrm{mg} / \mathrm{kg}, \mathrm{S} . \mathrm{C})$, showing congested glomerulus (thick arrows), and tubular dilatation with hyaline casts (arrows). E: Duodenum of the group $B$ treated with albendazole ( $20 \mathrm{mg} / \mathrm{kg}, \mathrm{S} . \mathrm{C})$, showing congested pelvis (arrows) in lamina propria with edema (star). H\&E. A, B, E X100, C, D X200

In the current study, albendazole caused a transient non significant decrease in WBCs count after one week of dosing that matches with the results obtained by Morris, Jourdan [23] who mentioned that albendazole elicited severe neutropenia post treatment.
The existing results showed that there were significant decreases

in the levels of lymphocytes and neutrophils compared with the control, which matches to some extent to Nwani, Odo [24]andYarsan, ALTINSAAT [25].
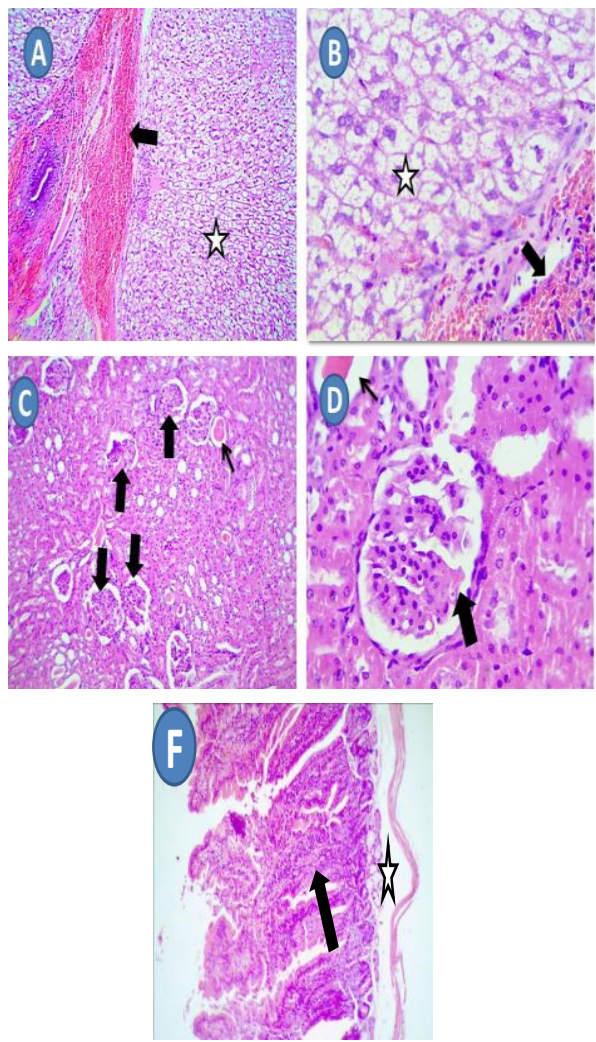

Figure 3: A\&B: Liver of the $3^{\text {rd }}$ group showing severe periductal hemorrhage (arrows) with hydropic degeneration of hepatocytes (star). C\& D: Kidney of the group $C$ showing necrotic glomeruli signs of acute inflammation (thick arrows) with tubular dilatation and tubular cast (thin arrow). F: D Duodenum of the group showing increased lymphocytic population in lamina propria villi (arrow) with edema in submucosa (star). H\&E. A, C, E X100, B, D X 200.

The excising findings of nitroxynil effects on total and differential leukocytic counts are agreed with that recorded by Khanam, Islam [26] and Islam, Mostafa [27]. Similarly, the WBCs results are in acceptance with Gray, Presson [19] and Tibbo [28] who indicated that TLC was significantly decreased in treated sheep and cattle.

The obtained results showed that albendazole and nitroxynil induced a significant increase in serum liver enzymes (ALT and AST) of treated rabbits.

Elevation in the activities of serum ALT and AST as observed by Huang, Lii [29]may be due to leakage from the organs into extracellular fluids due to change in endothelial permeability and that elevation indicated some forms of hepatic diseases in albendazole treated group is suggestive of damage to the plasma membrane of liver and cells leading to the increase in efflux of these enzymes into the extracellular fluid. ALT activity in blood was increased because of cells damage or death [30]. 
In addition, Opatrny, Snell [20]stated that AST and ALT were increased by albendazole because benzimidazoles are metabolized by the liver causing a decrease in liver oxidase systems and a greater inhibition of microtubulin dependent processes could leading to a great inflammation and toxicosis of hepatocytes. Furthermore, Dimitrijevic, Jovic [31] noted that albendazole and its metabolites accumulated in in the cell causing injury because it is very fat soluble drug. Additionally, Rivera, McClearen [32] connected the use of benzimidazole as albendazole and fenbendazole therapy in rabbits with hepatic enzyme elevation. Moreover, albendazole may cause some form of stress on liver cells and increased $\mathrm{Na}+\mathrm{K}+$ ATPase thus increasing the synthesis of the enzyme molecule to compensate this stress [33].

This results are matched with Jimoh and Odutuga [30]and Opatrny, Snell [20]who studied the effect of albendazole on serum AST and ALT that are elevated and recommended to monitor liver enzymes during albendazole therapy and discontinue treatment if elevations are noted.

The results of serum ALT and AST are in accordance to the results recorded by Elsawy, Elmaddawy [22] who stated that the activities of ALT and AST were significantly increased in nitroxynil treated rats after the $4^{\text {th }}$ and $8^{\text {th }}$ weeks of dosing.

These results are supported by the damage of liver obtained in histopathological findings due to liver damage and increasing the permeability of the cell membranes that also may ruptured so the enzymes diffused into the bloodstream and increased their serum levels [34, 35].

These results are supported by the findings reported by Hutchinson, Dawson [36] who found that injection of nitroxynil $(10.2 \mathrm{mg} / \mathrm{kg}$ B. wt. S.C) in cattle, increased AST and ALT above the rang8 and 11 week after treatment.

The obtained results of serum urea and creatinine showed that albendazole exerted a significant increase in serum creatinine level after one week and two weeks of treatment. While nitroxynil elevated serum creatinine after two weeks of dosing compared to control group. Additionally, there were a significant increase in serum urea after one day, one week and two weeks of albendazole and nitroxynil treatment.

The elevated serum urea and creatinine may be due to the increased serum bicarbonate level by albendazole in rats affecting $\mathrm{pH}$ of blood causing metabolic acidosis and the renal damage at reabsorption in the proximal tubules because kidney controls bicarbonate concentration [37].

Albendazole caused a high serum urea concentration and reduced renal blood flow that impair the secretory function of the kidney in rats [38]. Malfunction in the glomerular filtration results in the retention of substances including urea and creatinine, and this may be responsible for their high serum levels in all the treatment groups. Because albendazole caused a colloiddal osmotic pressure, which serves to maintain a normal blood volume and normal water content in the interstitial fluid and tissues so damage of kidney tissue [39]. In the same context, Ismail, Jayakody [40], mentioned that albendazole showed a minimal transient increase in serum creatinine after repeated administration of albendazole that confirmed our results of serum creatinine increase. Similarly, Whealton, Watson [38] reported that albendazole caused a minimal transient increase in serum creatinine and urea.

The findings regarding serum urea and creatinine are agreed with the results recorded by Elsawy, Elmaddawy [22] who recorded the levels of serum urea and creatinine which were significantly increased in nitroxynil treated rats. Our results showed that albendazole and nitroxynil treated groups showed a significant decrease in GSH after one day, one week and two weeks of treatment compared to control group. GSH, a cysteine-containing tripeptide, provides an important and ubiquitous cellular defense against oxidative stress, and also protects cells against other toxic insults such as xenobiotics and the infectious process [41].

Guengerich [42] and Dimitrijevic, Jovic [31] indicated that the biotransformation of albendazole passed through a series of reactions on CYP and FMO (reduction, protonation, addition of oxygen, hemolytic splitting of oxygen, etc.) reactive species of oxygen (ROS) and nitrogen (RNS) are generated. According to Dubin, Goijman [43], generation of ROS/RNS during redox cycling of nitroheterocyclic drugs which also include albendazole represents a determining factor for the intensity of peroxidative processes. The recorded results of GSH are agreed withPedrosa, de Bem [44] and Locatelli, Pedrosa [45] who recorded that there was an increase in GSH under albendazole treatment.

Locatelli, Pedrosa [45] mentioned that albendazole treated animals were unable of maintaining equilibrium between production and neutralization of ROS/RNS and avoiding adverse effect of these reactive species on the cellular homeostasis. Nitroxynil is an uncoupler of the oxidative phosphorylation in the cell mitochondria of the helminthes causing distribution of adenosine triphosphate (ATP) production depending on the oxide-reduction reactions for (ATP) production resulting in impairment of the parasites motility and other processes so after depletion of all its energetic reserves, the parasites die due to starvation $[4,46]$.

The uncouplers of oxidative phosphorylation as nitroxynil have a great affinity to binding to mitochondria of rat liver because they are lipophilic compounds that interactions may induce some configurational changes in the enzymes associated with oxidative phosphorylation and change the factors essential for this bioenergetic process [47]. The decrease in GSH is an indication of a severe oxidative insult to the hepatocytes elicited by albendazole[45]. The significant decrease in reduced glutathione (GSH) after nitroxynil therapy may be due to the effect of nitroxynil on small intestine that confirmed by the histopathological examination of duodenum 
showing several hemorrhages and inflammation because glutathione (GSH) is a tripeptide that constitutes one of the main intracellular reducing compounds that is synthesize in small intestine enterocytes inducing depletion in GSH and elicited an oxidant condition provoking oxidative/nitrosative stress and inflammation, which lead to apoptosis and autophagy of the enterocytes[48]. Similarly, the significant decrease in GSH following nitroxynil treatment is matched with the decrease of GSH following niclosamide that belongs to the same salicylanilides group that have the same mode of action by uncoupling mitochondrial oxidative phosphorylation [49].

That results are confirmed byÜstündağ and Buyukguzel [49] who indicated that niclosamide as one of salicylanilides exerted an oxidative stress and detoxification capacity on biological characteristics of the Drosophila melanogasterinsect so nitroxynil could has the same effect.

The present work mirrored a significant decrease in catalase after one week and two weeks in albendazole treated group was treated with albendazole in comparison with the control group. Also, there was a significant decrease in catalase in the group treated with nitroxynil after one day, one week and two weeks, compared to control group.

The decrease in GSH is an indication of a severe oxidative insult to the hepatocytes elicited by albendazole[45]. The significant decrease in reduced glutathione (GSH) after nitroxynil therapy may be due to the effect of nitroxynil on small intestine that confirmed by the histopathological examination of duodenum showing several hemorrhages and inflammation because glutathione (GSH) is a tripeptide that constitutes one of the main intracellular reducing compounds that is synthesize in small intestine enterocytes inducing depletion in GSH and elicited an oxidant condition provoking oxidative/nitrosative stress and inflammation, which lead to apoptosis and autophagy of the enterocytes[48]. Similarly, the significant decrease in GSH following nitroxynil treatment is matched with the decrease of GSH following niclosamide that belongs to the same salicylanilides group that have the same mode of action by uncoupling mitochondrial oxidative phosphorylation [49].

That results are confirmed by Üstündağ and Buyukguzel [49] who indicated that niclosamide as one of salicylanilides exerted an oxidative stress and detoxification capacity on biological characteristics of the Drosophila melanogaster insect so nitroxynil could has the same effect.

The present work mirrored a significant decrease in catalase after one week and two weeks in albendazole treated group was treated with albendazole in comparison with the control group. Also, there was a significant decrease in catalase in the group treated with nitroxynil after one day, one week and two weeks, compared to control group and GST with niclosamide therapy in Drosophyla melanogaster.
Malondialdehyde (MDA) revealed a significant increase after one day, one week of albendazole treatment then decreased to normal values after two weeks. On the other hand, nitroxynil elevated the serum MDA after one week and two weeks of dosing compared to the control one.

Lipid peroxidation in the form of Thiobarbituric acid reactive substances (TBARS) formation has been recognized as an important parameter for assessing free radical damage in animal tissues [51]. Albendazole induced an increase in TBARS contents in rat liver which is an indication of oxidative stress so elevated the MDA[24].

Pedrosa, de Bem [44],Locatelli, Pedrosa [45], Wojtkowiak-Giera, Wandurska-Nowak [52] and Nwani, Odo [24] gave an explanation of MDA results in rat after treatment with albendazole that the decrease of hepatic glutathione and glutathione-S-transferase activities and higher levels of lipid peroxidation elicited correspondingly greater inhibition of SOD, CAT, GPx, and GR activity at all albendazole concentrations. The higher values of these parameters may also be attributed to the more extensive reactions in the liver leading to higher risk of damage from oxidative stress and more limited antioxidant responses.

Furthermore, anthelmintics as niclosamide and nitroxynil have an oxidative stress and caused many changes in lipid peroxidation product, malondialdehyde (MDA) and protein oxidation products that increased MDA contents[49].

Our findings on liver tissue treated with albendazole may be due to the free radicals formed from albendazole biotransformation that occurred mainly in liver and in the presence of adequate oxygen, may lead to the generation of reactive oxygen species such as hydroxyl radicals and singlet oxygen among others which may disrupt membrane function and tissue protein and exert some harmful effects on the liver cells. Also, the high infiltration with polymorphonuclear cells in the liver sections suggests inflammatory response[53, 54].

These findings are in accordance to that were shown by Daly and Hogan [55] who found that there were minor hepatic changes in rat liver with albendazole therapy and showed centrilobular cloudy swelling and vacuolation or necrosis(at 45 $\mathrm{mg} / \mathrm{kg}$ ).Additionally, Arise and Malomo [56] reported that there was necrosis and high infiltration of polymorphonuclear cells and Kupffer cells in the liver of rats treated with albendazole when compared with control rats.

The reported histopathological findings by nitroxynil on the liver are in agreement with that reported by Elsawy, Elmaddawy [22] who recorded a congestion of the portal blood vessel, hepatocytic, hemorrhages and perivascular lymphocytic aggregation in rats liver post-nitroxynil treatment.

The treated with albendazole showed congested glomerulus, tubular dilation with hyaline casts. These 
alterations in kidney of the group B were in agree with that was mentioned by Arise and Malomo [56].

The results recorded in kidney of the nitroxynil treated group showed necrotic glomeruli signs of acute inflammation with tubular dilatation and tubular cast. These results are in accordance with Elsawy, Elmaddawy [22]who studied the histopathological changes of kidney in nitroxynil treated rats and indicated that there was cortical and medullary congestion, hemorrhages, lymphocytic infiltration, tubular dilation and tubular cast and excess of luminal casts in the cortical tubule at 8ththe weeks of the treatment. The existing results are matched with Alfonso, Marrero [57]who indicated that there was dilatation in renal tubules and hemorrhage after nitroxynil treatment.

Duodenum of the group B treated with albendazole showed congested pelvis in lamina propria with edema, Fig (2). On the other hand, duodenum of the $3^{\text {rd }}$ group treated with nitroxynil showed increased lymphocytic population in lamina propria villi with edema in submucosa, (Figure 3).

The disruption of intestinal mucosa after albendazole treatment may be due to the metabolism of albendazole that occurs in liver and small intestine leads to accumulation of the toxicant in the small intestine and detaching of the submucosal layer [53].

The existing results regarding the effects of albendazole on the duodenum were in acceptance with Moroni, Buronfosse [58] and Arise and Malomo [56] who found that the small intestine of rats showed greatly disrupted submucosa characterized by less affinity for stain and presence of plasma cells following administration of albendazole.

The current results of rabbit duodenum treated with nitroxynil was agreed with that shown by Sobbhy [59] and Alfonso, Marrero [57] who indicated that nitroxynil exerted congestion, hemorrhages in many organs. Similarly, Elsawy, Elmaddawy [22]stated that nitroxynil induced some histopathological changes in both liver and kidney of treated rats.

\section{CONCLUSION}

From the present study, it could be concluded that administration of nitroxynil and albendazole in rabbits induced a variety of adverse effects represented by alteration in blood picture. The drugs induced some degree of hepatic and renal damage that were confirmed by their effects on histopathological picture of liver, kidney, and duodenum. Moreover, the severity of oxidative stress elicited by the two drugs. The degree of these adverse effects was more serious with albendazole than nitroxynil therapy in rabbits.

\section{Acknowledgement: NA}

\section{Conflict of interest statement}

The authors declare that there is no conflict of interest in the current research work

\section{Animal Ethics Committee permission}

The current research work is permitted to be executed according to standards of animal Research committee in Faculty of Veterinary Medicine, Mansoura University.

\section{Authors' contributions}

Eman El-Alfy and Magdy Amer performed the experiment, statistical analysis, research writing; Magdy Amer and Azza Hassan revised manuscript and supervise the whole work

\section{REFERENCES}

[1] Gaber A. Clinic pathological studies on the effect of azithromycin in rabbits. Faculty of Vetrinary Medicine: Zagazig University; 2016

[2] Dyary HO. Veterinary anthelmintics and anthelmintic drug resistance. JZS 2016;18:91-206. https://doi.org/10.17656/jzs.10463

[3] Charlier J, van der Voort M, Kenyon F, Skuce P, Vercruysse J. Chasing helminths and their economic impact on farmed ruminants. Trends Parasitol J 2014;30:361-7. https://doi.org/10.1016/j.pt.2014.04.009

[4] Rahman MM, Kabir A, Ahmed S, Islam MK, Rahman MS, Alam A, et al. Nitroxynil uncouples oxidative phosphorylation in the cell mitochondria and a drug wherever injectables are preferred over drenches. Bangladesh J Vet Med. 2017;15:45-9. https://doi.org/10.3329/bjvm.v15i1.34054

[5] Junquera J. Parasites of Dogs, cat, Livestock : Biology and control. Vet J. 2007;3:3455.

[6] Shaikh B, Rummel N, Gieseker C, Cheely C-S, Reimschuessel R. Residue depletion of albendazole and its metabolites in the muscle tissue of large mouth and hybrid striped bass after oral administration. J Chromatogr A. .2009;1216:8173-6. https://doi.org/10.1016/j.chroma.2009.04.009

[7] Kuhlmann FM and Fleckenstein JM. Antiparasitic Agents. Infectious Diseases: Elsevier; 2017. p. 1345-72.e2. https://doi.org/10.1016/B978-07020-6285-8.00157-X

[8] Lucas JMS. 4-Cyano-2-lodo-6-Nitrophenol, M\&B 10,755* *Alternative name is 3-iodo-4-hydroxy-5-nitrobenzonitrile. $\mathrm{Br}$ Vet J. 1967;123:198211. https://doi.org/10.1016/S0007-1935(17)40004-2

[9] Coles MA, Brown DF. "Staphaurex" negative, methicillin resistant Staphylococcus aureus. Am J Clin Pathol. 1986;39:1365https://doi.org/10.1136/jcp.39.12.1365

[10] Tietz NW, Sanders WB. Fundamentals Of Clinical Chemistry Co. Philladelphia: Saunders 1976.

[11] Vassault A, Grafmeyer D, Naudin C, Dumont G, Bailly M, Henny J, et al. Protocole de validation de techniques. Ann Biol Clin. 1986;44:686-745.

[12] Henry RG. Clinical Chemistry. New York: Harper And Row; 1964.

[13] Beutler E. Improved method for the determination of blood glutathione. J lab clin Med. 1963;61:882-8.

[14] Kei S. Serum lipid peroxide in cerebrovascular disorders determined by a new colorimetric method. Clinica Chimica Acta. 1978;90:37-43. https://doi.org/10.1016/0009-8981(78)90081-5

[15] Aebi H. Methods in enzymatic analysis. New York: Academic press; 1984.

[16] Bancroff JP, Stevenes A, Turner DR. Theory and Practice ofHistological Techniques, third Ed. Edinburgh, London: Clurechill Livingston; 1990.

[17] Snedoecor GW, Cochoran NG. Statistical Methods, 6th Ed. Ames The Lowa State University Press; 1981.

[18] Short CR, Flory W, Hsieh LC, Barker SA. The oxidative metabolism of fenbendazole: a comparative study. JVPT. 1988;11:50-5. https://doi.org/10.1111/j.1365-2885.1988.tb00120.x 
[19] Gray GD, Presson BL, Albers GAA, LeJambre LF, Piper LR, Barker JSF. Comparison of within-and between-Breed Variation in Resistance to Haemonchosis in Sheep. In: McGuirk BJ, editor. Merino Improvement Programs in Australia. Melbourne, Australia: Australian Wool Corporation; Int J Parasitol . 1987. p. 365-9.

[20] Opatrny L, Snell L, Prichard R, Maclean JD. Death related to albendazoleinduced pancytopenia: Case report and review. AM J TROP MED HYG. 2005;72:291-4. https://doi.org/10.4269/ajtmh.2005.72.291

[21] Graham JE, Garner MM, Reavill DR. Benzimidazole Toxicosis in Rabbits: 13 Cases (2003 to 2011). J Exot Pet Med. 2014;23:188-95. https://doi.org/10.1053/j.jepm.2014.02.012

[22] Elsawy A, Elmaddawy Z, Mohamed N. Adverse Effects of Nitroxynil in comparison with Levamisole on Male Rats. Alex J Vet Sci. 2015;47:14857. https://doi.org/10.5455/ajvs.199012

[23] Morris DL, Jourdan J-L, Pourgholami MH. Pilot Study of Albendazole in Patients with Advanced Malignancy. Oncology. 2001;61:42-6. https://doi.org/10.1159/000055351

[24] Nwani CD, Odo GE, Nwadinigwe AO, Onyeke CC, Atama Cl, Ngwu G, et al. Short-Term Effects of Albendazole on the Oxidative Stress Markers and Hematological Parameters in Tissues of African CatfishClarias gariepinus. J Aquat Anim Health. 2016;28:222-8. https://doi.org/10.1080/08997659.2016.1194908

[25] Yarsan E, Altinsaat Ç, Ayçiçek H, Şahindokuyucu F, Kalkan F. Effects of albendazole treatment on haematological and biochemical parameters in healthy and Toxocara canis infected mice. TURK J VET ANIM SCI. 2003;27:1057-63.

[26] Khanam S, Islam M, Aktaruzzaman M, Hossain M, Hossain M, Hossain M, et al. Effects of triclabendazole and nitroxynil on EPG, hematological parameters and body weight against fascioliasis in goats at government goat development farm, Sylhet, Bangladesh. Int J Nat Sci. 2015;5:46-51. https://doi.org/10.3329/ijns.v5i2.28611

[27] Islam A, Mostafa M, Awal M, Islam M, Alam J, Rahman M, et al. Efficacy of ivermectin against gastrointestinal rematodes and ectoparasites in calves. Indian Vet J (India). 2003;80:1173-6.

[28] Tibbo M. The effect of Triclabendazole (Fasinex ${ }^{\circledR}$ ) on acute fasciolosis in sheep in central highland of Ethiopia. AU-IBAR. 2000;48:87-92.

[29] Huang T-H, Lii C-K, Chou M-Y, Kao C-T. Lactate dehydrogenase leakage of hepatocytes with $\mathrm{AH} 26$ and $\mathrm{AH}$ Plus sealer treatments. J Endod. 2009;26:509-11. https://doi.org/10.1097/00004770-200009000-00005

[30] Jimoh F, Odutuga A. Changes in the activities of some diagnostic enzymes in some rat tissues following the consumption of thermally oxidized groundnut oil. Nig J Biochem Mol Biol. 2001;16:173-6.

[31] Dimitrijevic B, Jovic S, Ostojic-Andric D, Savic M, Beckei Z, Davidovic V, et al. Infection with Strongyloides papillosus in sheep: Effect of parasitic infection and treatment with albendazole on basic haematological parameters. Biotechnol Anim Husb. 2016;32:369-81. https://doi.org/10.2298/BAH1604369D

[32] Rivera S, McClearen J, Reavill D. Suspected fenbendazole toxicity in pigeons (Columba livia). Proceedings of the association of Avian Veterinary Conference. Portland,OR2000. p. 207-9.

[33] Malomo S, Daramola A, Balogun E. Some serum and tissue enzyme changes in mice infected with Plasmodium yoelii nigeriensis before and after administration of halofantrine hydrochloride. Niger J Biochem Mol Biol. 1995;10:71-7.

[34] Doxy DL. Veterinary Clinical Pathology 1st Ed. London: W.B. Saunders Company; 1971.

[35] Hoe CM, Wilkinson JS. LIVER FUNCTION: A REVIEW. AUST VET J. 1973;49:163-9. https://doi.org/10.1111/j.1751-0813.1973.tb06770.x

[36] Hutchinson GW, Dawson K, Fitzgibbon CC, Martin PJ. Efficacy of an injectable combination anthelmintic (nitroxynil+clorsulon+ivermectin) against early immature Fasciola hepatica compared to triclabendazole combination flukicides given orally or topically to cattle. Vet Parasitol. 2009;162:278-84.

[37] Ganong WF. Review of Medical Physiology, 19th Ed. New York: Lange Medical Books. McGraw Hill Companies Inc; 1991.

[38] Whealton A, Watson AJ, Rock RC. Colorimetric Determination ofserum urea concentration. In: Burtis CA, Ashwood ER, editors. Tietz Textbook of Clin Chem. London: WB Saunders Company 1994. p. 1528-31.
[39] Malomo S, Adebayo J, Arise R, Olorunniji F, Egwim E. Effects of ethanolic extract of Bougainvillea spectabilis leaves on some liver and kidney function indices in rats. J Pharmacogn Phytochem . 2007;17:261-72.

[40] Ismail MM, Jayakody RL, Weil GJ, Nirmalan N, Jayasinghe KSA, Abeyewickrema W, et al. Efficacy of single dose combinations of albendazole, ivermectin and diethylcarbamazine for the treatment of bancroftian filariasis. Trans R Soc Trop Med Hyg. 1998;92:94-7. https://doi.org/10.1016/S0035-9203(98)90972-5

[41] Meister A. Selective modification of glutathione metabolism. Sci. 1983;220:472. https://doi.org/10.1126/science.6836290

[42] Guengerich FP. Cytochrome P450 and Chemical Toxicology. Chem Res Toxicol. 2008;21:70-83. https://doi.org/10.1021/tx700079z

[43] Dubin M, Goijman SG, Stoppani AOM. Effect of nitroheterocyclic drugs on lipid peroxidation and glutathione content in rat liver extracts. Biochem. Pharmacol. 1984;33:3419-23. https://doi.org/10.1016/0006 2952(84)90114-X

[44] Pedrosa RC, de Bem AF, Locatelli C, Pedrosa RC, Geremias R, Filho DW. Time-dependent oxidative stress caused by benznidazole. Redox Rep. 2001;6:265-70. https://doi.org/10.1179/135100001101536328

[45] Locatelli C, Pedrosa RC, De Bem AF, Creczynski-Pasa TB, Cordova CAS, Wilhelm-Filho $D$. A comparative study of albendazole and mebendazoleinduced, time-dependent oxidative stress. Redox Rep. 2004;9:89-95. https://doi.org/10.1179/135100004225004751

[46] McKinstry B, Halferty L, Brennan GP, Fairweather I. Morphological response of triclabendazole-susceptible and triclabendazole-resistant isolates of Fasciola hepatica to treatment in vitro with nitroxynil (Trodax). Parasitol Res. 2008;104:645-55. https://doi.org/10.1007/s00436-008-1241-8

[47] Weinbach EC, Garbus J. Protein as the Mitochondrial Site for Action of Uncoupling Phenols. Sci. 1964;145:824-6. https://doi.org/10.1126/science.145.3634.824

[48] Moine L, Rivoira M, Barboza GDd, Pérez A, Talamoni NTd. Glutathione depleting drugs, antioxidants and intestinal calcium absorption. World J Gastroenterol. https://doi.org/10.3748/wjg.v24.i44.4979

[49] Üstündağ G, Buyukguzel E. The Effect of Niclosamide on Certain Biological and Biochemical Properties of Drosophila melanogaster. CENT EUR J BIOL. 2019;78:29-38. https://doi.org/10.26650/EurJBiol.2019.0003

[50] Cervera A, Maymó AC, Martínez-Pardo R, Garcerá MD. Antioxidant Enzymes in Oncopeltus fasciatus(Heteroptera: Lygaeidae) Exposed to Cadmium. Environ Entomol. 2003;32:705-10. https://doi.org/10.1603/0046-225X-32.4.705

[51] Dar SA, Yousuf AR, Balkhi M-u-H, Ali MN. Oxidative stress in the freshwater cyprinid crucian carp (Carassius carassiusL.) upon chronic exposure to endosulfan. Toxicol Environ Chem. 2014;96:906-16. https://doi.org/10.1080/02772248.2014.982122

[52] Wojtkowiak-Giera A, Wandurska-Nowak E, Michalak M, Derda M, Lopaciuch J. Trichinellosis in mice: effect of albendazole on the glutathione transferase in the intestines. Folia Parasit. 2012;59:311-4 https://doi.org/10.14411/fp.2012.044

[53] Davis A, Dixon H, Pawlowski Z. Multicentre clinical trials of benzimidazolecarbamates in human cystic echinococcosis (phase 2). B World Health Organ 1989;67:503-8.

[54] Buronfosse T, Moroni P, Beno??t E, Rivière JL. Stereoselective sulfoxidation of the pesticide methiocarb by flavin-containing monooxygenase and cytochrome P450-dependent monooxygenases of rat liver microsomes. Anticholinesterase activity of the two sulfoxide enantiomers. J Biochem Mol Toxic. 1995;10:179-89. https://doi.org/10.1002/jbt.2570100402

[55] Daly IW, Hogan GK. A long-term oral dietary toxicity carcinogenciity study of albendazole in rats. Biodynamics. Submitted to WHO by SmithKline and French. 1982:2379-83.

[56] Arise RO, Malomo SO. Albendazole potentiates the neurotoxic effect of ivermectin in rat. IJBCS. 2012;6:1-5.

[57] Alfonso H, Marrero E, Cabrera C. Median lethal dose for mice of the fascioliasis nitroxynil and niclofan. Rev. Salud Anim (Cuba). 1984;66:10512. https://doi.org/10.4314/ijbcs.v6i1.28 
[58] Moroni P, Buronfosse T, Longin-Sauvageon C, Delatour P, Benoit E. Chiral sulfoxidation of albendazole by the flavin adenine dinucleotidecontaining and cytochrome P450-dependent monooxygenases from rat liver microsomes. Drug Metab Dispos. 1995;23:160-5.
[59] Sobbhy HM. Effects of nitroxynil on fetal development ,sexual organs weight and epididymal sperm characters in rats. J Egypt Com Path \& Clinic Path. 1977;10:64-73 